\title{
Traces, bones, desert: the extermination of the Armenians through the photographer's eye
}

\author{
Anouche Kunth Centre National de la Recherche \\ Scientifique \\ anouche.kunth@gmail.com
}

\begin{abstract}
$^{1}$
Braving the Ottoman's ban on capturing any images of the persecuted Armenians, witnesses dodged censorship and photographed pictures that would later be branded as proof at the Paris Peace Conference in 1919-20. Despite the challenge of these images to representations of the Armenian genocide, they were soon forgotten after the 1923 Treaty of Lausanne erased the Armenian Question, while time took care of destroying the corpses abandoned in the desert. This article will examine the image-disappearance dialectic through distinct temporalities of remembrance and commemoration, each of which mobilises its own specific, iconographical semantics. In response to contemporary challenges, the repertoire of images has not remained sealed; over the last decade it has been reopened through depictions of bare landscapes and stretches of desert and bones that suddenly pierce through the earth. The article will show how these images implicitly speak of the disappearance and seek meaning through emptiness.
\end{abstract}

Key words: Armenian genocide, denial, image, icon, erasing memory

The 'cloud of denial and unknowing' ${ }^{2}$ that has long prevented the world from knowing clearly about and comprehending the genocide of the Armenians was, and still is, a challenge to its representation. Photography strove to meet this challenge right from the perpetration of the crime when, braving the official ban on capturing any image of the persecutions that were taking place, eyewitnesses took rare pictures that would be held up as proof after the First World War. These images added to the abundant written documentation that the Armenian delegates presented at the Paris Peace Conference in 1919-20. In return, they received the promise that the leaders of the Young Turks would be forced to answer for their crimes. However, as a result of political inconsistency, the Armenian Question slipped off diplomatic agendas before a fitting solution could be given. As a consequence of this political erasure, the narrative and iconographical material on the extermination of the Armenians almost disappeared from circulation, while time took care of destroying the corpses abandoned in the desert.

This triple disappearance, swept into the dark corners of history, draws our 
attention to the place of photography in the remembrance of genocide. In truth, this study owes much to a whole body of works. Some of these have studied the photographic corpus and its uses, ${ }^{3}$ and others have proposed a semiology of the image. ${ }^{4}$ Building on these advances, this article aims to look more closely at the historical progression that has by turns placed images in the position of powerless mediators, icons subject to manipulation and symbolic sanctuary for the last traces. From photo-document to artistic image, ${ }^{5}$ the article will detail the temporalities specific to the different roles of photography so that we can better observe the particular importance that each period attaches to images, to the point where there is a desire to create new ones. Thus, the question of the articulation of collective memory with the photographic image requires us to historicise the paths taken, be they militant or aesthetic, in order to fight the negation and forgetting of a crime with a clear representation of destruction.

\section{Rare images, escaping censorship}

'The order is given to destroy all the photographs that have been taken, which proves the extent of the fear that it will come to light.' ${ }^{6}$ This was the comment made in 1919 by the author of the Livre Rouge, Grigor Tchalkhouchian, an Armenian from Russia who wanted to help denounce the crimes perpetrated by the Union and Progress Committee. ${ }^{7}$ He writes '[W]hat Turkey will say in response at the tribunal, I do not know, but I speak for Armenia', explicitly offering himself as a spokesperson for an Armenia soon to be heard at the 'Tribunal of the Great Peoples' at the 1919-20 Paris Peace Conference. ${ }^{8}$ The photographic act, as these words remind us, is inseparable from certain expectations: in this case, a quest for truth and justice.

During the war, circumstances greatly discouraged images being taken of the Armenians' persecution. This was firstly because eyewitnesses knew that any attempt to break measures to hide the crime meant risking their lives. ${ }^{9}$ Secondly, they did not always have the necessary equipment, not to mention the fact that, until the invention of lightweight equipment, technical constraints made it difficult to transport heavy and cumbersome apparatus to the remote places where the Armenian deportees were taken. ${ }^{10}$ Against all odds, some succeeded, undoubtedly confident that the scenes photographed would one day become proof. ${ }^{11}$ The motivation to record images as part of a witnessing process grew even stronger when, on 24 May 1915, the Entente Allies solemnly warned the Ottoman Government that it would be held responsible for the 'new crimes against humanity and civilization' targeting the Armenian population. ${ }^{12}$ It was time for justice to be done. ${ }^{13}$

Thirty-two images on glass plates escaped Ottoman censorship. ${ }^{14}$ This is the inestimable legacy of Armin Wegner (1886-1978), author of the main photographic collection on the extermination of the Ottoman Armenians. ${ }^{15}$ This volunteer nurse secretly brought back the majority of the photographs taken in Syro-Mesopotamian concentration camps ${ }^{16}$ following his nursing work alongside the Sixth Ottoman Army. ${ }^{17}$ Unable to take many of the images of the atrocities himself, he thought it essential to obtain them from German officers. ${ }^{18}$ These 
images showing the emaciated bodies of the dead and the suffering are some of the most famous in the Wegner Collection, which is now kept at the Deutches Literaturarchiv in Marbach, Germany.

Another means of access to the entrenched space of the massacres was opened up from the Caucasian front, after the Russian's January 1916 military offensive partially liberated the way to Ottoman Armenia. The Tsarist troops here photographed ruins and the mass graves. ${ }^{19}$ Following in their footsteps, Henry Barby, a French journalist working as a war correspondent for Le Journal, arrived in Erzurum. His expedition gave rise to an account, $A u$ Pays de L'épouvante [In the Land of Terror], published in Paris in 1917. ${ }^{20}$ The work is accompanied by photographs, not all of which are Barby's own. In fact, struck by the sight of starving children, Barby published three of his own photographs taken in Armenian orphanages in Tiflis. ${ }^{21}$ With the full-length portraits of Armenian resistance members, these pictures of orphans make up the majority of the iconography among the accounts of suffering. Barby only tells of death in words and not in any other form. This visual omission is made even more striking by the fact that the journalist himself describes 'the startling eloquence [of the] infinite ruins, devastation and death' without providing any pictorial representation of this atrocious landscape. ${ }^{22}$ The essential remains out of shot. We will return to this observation later.

In October 1916, with the Russians still occupying certain Turkish provinces, a Georgian journalist, Levan Kipiani, went to the site of a massacre perpetrated in Baskane in June 1915. ${ }^{23}$ With a local citizen as his guide, Kipiani took the path trodden by 1,700 Armenian families before him (in their case, never to return). Beginning his journey, he must have quickly noticed the care taken to erase the traces of the crime - the removal of corpses, taken 'as far away as possible' and thrown into ravines and holes where nobody could see them. ${ }^{24}$ 'However', he goes on, 'as the road climbs, we increasingly start to see dried bodies, lying in the yellow grass'. He then turns his attention to the human remains encountered, giving an almost clinical description. Notably, Kipiani looks at the bodies to see how they died.

Particularly well preserved are the hands and feet. By their position, the form of their convulsively clenched and swollen fingers, they speak so eloquently of the tragedy that took place here fourteen months ago! The crossed legs of the women and their fingers clutching at their arms are so telling of the abominations that took place here! The marks of blades and firearms are obvious on the corpses. ${ }^{25}$

As Kipiani states here, the bodily mutilations tell the manner of death. They tell us what the killer did. For this very reason, and by way of comparison, the exhibition of the bleached bones and limed bodies in Rwanda's Tutsi genocide memorials is part of a radical educational choice to ensure that the genocide is remembered by the physical fact of the tortured bodies. ${ }^{26}$ This demonstration is the result of a policy of seeking out and opening mass graves not only to exhume and identify the bodies before giving them a dignified burial, but also to analyse the bodies as a source, a way of understanding the massacre. In Rwanda, the establishment 
of criminal courts operating both at the local level (the gacaca $^{27}$ tribunals) and at the international level (the $\mathrm{ICTR}^{28}$ ) was decisive in making the bodies a subject of investigation in themselves.

However, at the time when Kipiani was examining the corpses, it was not selfevident that mass crimes could be comprehended via bodies. The official organisations that took charge of the Armenian case from 1918 gave priority to written material. ${ }^{29}$ The important consideration was to prove criminal intention, where efforts were focused on collecting directives, circulars and telegraph orders that had not been hidden or destroyed, and on collecting and publishing the statements of Armenian escapees, foreign people present in the Ottoman Empire at the time when the events took place ${ }^{30}$ and even Turkish state agents. ${ }^{31}$ In the Russian Caucasus, where over three hundred thousand Armenian refugees were sheltered, efforts focused on transcribing initial statements.

What of the over one million corpses during this first phase of understanding the genocide? They haunt the testimonies - they are bundles drifting in the waves of the Euphrates, or shapeless mounds at the bottom of precipices. However, there were too many obstacles for them to be either captured in photographs or fully perceived by contemporaries. This was because although the provinces of Ottoman Armenia were partly visible during the period of Russian occupation, they once again became inaccessible when they came back under Turkish control. The zone was closed to any attempt to look for graves, while the opposite was true of the Syrian provinces placed under French mandate after the war. ${ }^{32}$ Thus, on the Turkish side, the remains decomposed out of sight, some in quicklime, ${ }^{33}$ others in the open air, abandoned to the weather and animals. ${ }^{34}$

As already stated, there were eyewitnesses to take photographs. During the war, some of these photographs were published in the Western press for propaganda purposes against the central empires. The peace settlement then required that their publication be stopped. Lost in limbo, they remained the prisoners of a political temporality, which we must now consider in order to understand the resurgence of shock images after decades of erasing and forgetting.

\section{From erasing to remembering}

The unclear, not to mention underground, journeys that the photographs of the Armenian genocide underwent before they re-emerged make it necessary to examine the time lag during which the event remained underexposed - outside history's door and on the wrong side of the threshold, at which the past acquires a status in collective memory.

It may initially seem astonishing that the Armenian delegates themselves did not include the photographs in the publications that they officially submitted to the Paris Peace Conference. ${ }^{35}$ However, at the end of 1918, the Armenian writer Zabel Essayan (1878-1943) ${ }^{36}$ - who, in the words of Marc Nichanian, became 'secretary of the survivors ${ }^{\prime 37}$ - transported abundant documentation destined for the conference from the Caucasus to Paris. We know that it included photographs, most likely taken by Russian officers. ${ }^{38}$ However, it is impossible to say exactly which 
photographs this concerned, because the material fate of the file is still unknown today, and the publications of the time do not allow us to retrace its appearance. During this same period, one of high political and judicial stakes for the Armenians, the documentation published in Paris by Aram Andonian, contained a small series of photographs. However, these show no scenes of violence directly linked to the genocide. ${ }^{39}$

Nevertheless, we should avoid interpreting this poor circulation of the images of violence immediately following the war as indicating a trend of the genocide's political negation. Leaving aside the primacy of written sources at this time, the phenomenon actually seems to indicate that there was, at the time, no mystery about the event. ${ }^{40}$ Moreover, as long as the Peace Conference was still going on, the Armenian Question seemed destined to receive the most dignified solution possible. Thus, by stipulating the creation of an Armenian State separate from Turkey - which would be free and independent - the Treaty of Sèvres (10 August 1920) sought to satisfy Armenian national demands; Sèvres also followed the recommendations of the Committee of Fifteen at the Peace Conference, advising the creation of an international criminal tribunal to judge those responsible for the crimes against the Armenians. ${ }^{41}$ However, after the Allies took the side of the Turkish National Movement, none of this came to pass. Although we are not attempting here to explain the reasons for such a turnaround, it is important to emphasise that it accelerated the eviction of the Armenian Question from the international scene. Two points are sufficient to illustrate this: firstly, the abandonment of the independent nation-state project - with the peace negotiated in the Treaty of Lausanne in 1923 actually exiling and scattering the Armenians - leaving them stateless; ${ }^{42}$ and secondly, the Allies' renunciation of their desire for justice, with an appendix to the Lausanne Treaty proclaiming a general amnesty for all the crimes committed by the Turkish leaders from 1914 to $1922 .{ }^{43}$

In other words, without the political will to move the lines of international law to encapsulate the specificity of crimes against humanity, the assassination of the Armenians would soon be forgotten. However, the fate of Armenia continued to cause agitation in pro-Armenian circles, in which the most eminent figures put pen to paper in order to denounce the attitude of the powers, although, once again, the examination of a sample of the memoirs published in France and Switzerland in the interwar period shows a striking absence of shock images (as we might call the photographs which later became emblematic of the Armenian's extermination). ${ }^{44}$ By contrast, in America, images of lifeless bodies had soon appeared in the press. ${ }^{45}$ Moreover, the rise of the young cinematographic industry had opened up new perspectives for American screenwriters, who seized upon the testimony of a young female escapee in order to offer the public a sensationalist film, Ravished Armenia (1919), in which the (toned down) scenes of violence were played by the victim herself. ${ }^{46}$ Nevertheless, as observed by Sévane Garibian, the 'mysterious disappearance' of the film in the 1920s coincides with the abandonment of the Armenian case by the Allies and the implementation of a negationist state policy in Turkey. ${ }^{47}$

This quick introduction to the images' entry into circulation has not yet done justice to the German networks. From 1922 it was, in particular, German army 
officers who made it possible for Father Balakian to accompany his testimony with images clearly showing the tortured bodies. ${ }^{48}$ Germany did not welcome the Armenians on the scale of France, where over sixty thousand refugees went to live during the 1920s. However, it was in this country, a former ally of the Ottoman Empire, that early imaginings of the tragedy suffered by the Armenians crystallised. Several factors contributed to this, including the aggressive campaign of denunciation from 1915 by the pastor Johannes Lepsius, who had returned from Constantinople with precise information on the deportations that were taking place. $^{49}$

We must also look again at the work of Armin Wegner, a major witness to the extermination of the Armenians who, faced with this horror, became an improvised photographer against all odds. After the war, he made a point of denouncing the horrors committed by the allies of the Reich to his compatriots. He also held 'illustrated conferences', ${ }^{50}$ where the photographs he had brought back from the Ottoman Empire were projected. Then, in June 1921 at the time of the (momentous) trial of Soghomon Tehlirian, ${ }^{51}$ Wegner was called upon to act as an eyewitness to the genocide. He even offered to present to the jurors photographs he possessed, in support of his statement, but in the end the tribunal had enough proof to make its judgment, so it seems this never occurred. Wegner did not even appear. ${ }^{52}$

After the Armenian Question was abandoned in Lausanne in 1923, macabre pictures of the Armenians were still being exhibited in Germany, this time on the initiative of a committed conscientious objector who was attempting to demystify the war. To this end, in 1924, Ernst Friedrich published a collection of photographs, aptly entitled Krieg dem Kriege! [War against War!]. ${ }^{53}$ Produced in four languages, ${ }^{54}$ the work offers ad nauseam the rawest images of the battlefields, in the hope of dissuading people from this murderous choice. This is the 'true face' of war, the author emphasises, bombarding readers with photographs that were mostly taken from the German military and medical archives that had been selected for their revulsion value. ${ }^{55}$ All are accompanied by a caption - or rather a caustic comment - that strongly denounces the manipulation of minds. As the work goes on, the bleak images of the military front give way to the violence inflicted on civilians. Three photographs taken from Armin Wegner's collection offer new visual variations on this aspect of the brutality. ${ }^{56}$ The chosen images show corpses that are naked or in rags and alone or in groups. In two of the photographs, the victims are children; the caption proclaims that they died of hunger. Such a tragedy might have been attributable to the disturbance of economic circuits in times of war, had the author not identified them as 'Armenians robbed of their homeland and left to perish from hunger and fatigue by the wayside. Hundreds of thousands were to die in this way (pay attention here: hundreds of thousands!). ${ }^{57}$

In spite of these expectations and the publication in 1933 of a German-language historical novel that was inspired by a feat of Armenian resistance, ${ }^{58}$ Adolf Hitler dismissed the doubts of his generals, asking: 'Who still talks nowadays of the extermination of the Armenians? 59 This simple phrase, pronounced shortly before the invasion of Poland, speaks volumes about how the event occurred without finding a full place in the minds of people at the time. 
On the fiftieth anniversary of the genocide, which fell on 24 April 1965, the sons and daughters of the survivors took to the streets of Yerevan (the capital of Soviet Armenia), Paris and Montreal, among others, to demand justice, after decades of discreet commemoration and apparent resignation. ${ }^{60}$ At the end of the First World War, the Armenian representatives faced something never before considered in the juridical world. Now, however, mobilisation could hinge upon the concept of genocide, whose status as a criminal offence was established on 9 December 1948 in the Convention on the Prevention and Punishment of the Crime of Genocide adopted by the United Nations. ${ }^{61}$ This new age of combat for recognition of the genocide would also draw on iconographic material.

In fact, during the April 1968 commemorations, the revitalisation of the Armenian movement drove Armin Wegner to place some of his historical photographs in the Casa Armena in Milan and to authorise their reproduction. ${ }^{62}$ Then, in 1975, this time marking the sixtieth anniversary of the genocide, a pioneering work was published: Jean-Marie Carzou's Un Génocide Exemplaire, Arménie 1915 [An Exemplary Genocide, Armenia 1915], which was accompanied by a booklet of photographs. ${ }^{63}$ Instead of this booklet providing rigorous captions to accompany the photographs, there are comments that take the same accusing register as that used fifty years earlier by the author of Krieg dem Kriege!. Here, the photographs act as emblems. Such a use of photography allowed for approximations, if not errors in dates and attribution. ${ }^{64}$ What mattered was that the images of the past formed a pillar of collective representations that were indispensable to the public's remembrance of an event that history had forgotten. In 1995, the organisation by a French diaspora association of an exhibition devoted to images of the genocide marked the peak of this process. ${ }^{65}$

Still, we are left with an ontological question: how do we give a tangible incarnation to an immeasurable crime, one that for this very reason is irreducible to any attempt to fully capture it in photography? We are forced to admit that its mass extent rarely comes across. The technical means of the period and the reign of secrecy did not allow contemporaries to capture the massacres. Nor could they take panoramic shots of concentration camps or mass graves. ${ }^{66}$ Remembering therefore took place at another level, favouring photographs of vulnerable people: emaciated women and children who became symbols of suffering that the Western spectator can easily associate with the classical repertoire of Christian iconography. In one photograph, a Mater Dolorosa holds her child out in front of her. In another, we see a further massacre of the Innocents. ${ }^{67}$ Consequently, in images, it is the register of brutality that comes across, rather than genocidal rationality.

\section{The new aesthetic frameworks of memory}

In a world where violence is constantly broadcast on our screens, thereby condemning the event to exist only through the spectacle of information, a need has arisen to renew the visual language on the events of $1915 .{ }^{68}$ In order to maintain links with an increasingly distant past, it becomes necessary to go beyond the invariable reproduction of original images. The past needs to be expressed in forms 
that the people of the present could understand. In other words, the missing images need to be created. ${ }^{69}$

Time, which sweeps away the remnants and the survivors, is not the only driver for this aesthetic reworking. The persistence of the Turkish State in denying the facts and, in the same move, escaping the international obligation to shed light on crimes against humanity (for example by looking for the mass graves), created a need for a reflective approach to images. This approach would play on the boundaries between the visible and the invisible, the real and the allegorical, in order to address the annihilation of the Armenians.

Faced with the multiplication of perspectives, the analysis is necessarily limited to a few photographic proposals. Three main directions emerge, though they are not mutually exclusive. The first searches the bare landscapes and embraces stretches of desert, seeking meaning through emptiness. In contrast, the second is reminiscent of the project of microhistory. ${ }^{70}$ It shares the same taste for detail, looking at the physical environment for the traces of a silent legacy. In this quest, photography succeeds in capturing bones that have come back to the surface, making the medium more than a mere receptacle: it is a refuge for abandoned remains. Finally, the third approach focuses on the living, using them to better grasp the presence of the disappeared. In all cases, the authors use photography as a means of understanding the catastrophe in the present.

Of the three enigmas facing photography, the enigma of the void is closest to the intimate link between genocidal mechanics and space. It is important to remember that the elimination of the Armenians drew very concretely on topography by using gorges, rivers and ravines to kill and as a place to dispose of or pile up the bodies. During the second phase of the genocide, the deportees who survived the death marches were abandoned to the deserts of Syria and Mesopotamia. ${ }^{71}$ Here, they were kept in death camps, where hundreds of thousands died. The slowest to die (tens of thousands of prisoners) were massacred away from the camps in remote and expansive terrains or taken to be burned alive in underground caves, where natural-gas fumes helped the flames to catch.

As already stated, there are only a few rare images of these events, taken particularly in concentration camps. What is striking in comparison to the images of Nazi or Soviet camps are the frail installations: simple tents clumsily set up on the sandy soil. There is no material or permanent construction that symbolises oppression in the way that barbed wire did in the totalitarian era. ${ }^{72}$ Instead, the photographs give an impression of anarchy, or even amateurism, allowing doubt to be cast on the criminal's intention: were they really seeking to commit mass murder with such poor means? The cogs of the genocidal machine are therefore unclear, unless we understand that, in part, they are here before our eyes in the infernal desert surroundings. But disappearing this way, in the heart of wild nature, creates a risk that their status as victims of a state crime will itself become denatured through the appearance of a non-human instigated death, such as, for example, being victim to an unfortunate drought. 'So? Did we dream this genocide?' Carzou asked, echoing the silence surrounding this page of history in the 1970 s. $^{73}$ 
It is significant to note that immediately following the genocide the Jesuit Antoine Poidebard was addressing the extermination of the Armenians through emptiness, publishing a photograph called 'Panorama des Montagnes d'Arménie, lieux de Massacres' ('Panorama of the Armenian Mountains, the Sites of Massacres'). ${ }^{74}$ It shows nothing other than the bottom of a mountain chain rising up in the loop of a river. In the foreground is a man (undoubtedly Poidebard's guide) who is holding horses. In short, the major themes that would later be used to address the Armenian genocide are already present: invisibility of the bodies, hiding by nature, and memory dismissed for lack of evidence.

Judging by the works of the generation of photographers born in the 1960s and 1970s, it is clear that the landscape is at the centre of an exploration attempting to establish a dialogue with history. ${ }^{75}$ The disappearance of the last survivors is certainly no stranger to this approach to genocide via its spatial footprint. The same goes for other genocides besides the one examined here. Poland's rich, green, natural palette of damp forests and plains is shown in the photography of Roberto Frankenberg, who visited the places to which his ancestors were deported and assassinated. Consequently, the names Majdanek, Sobibor and AuschwitzBirkenau are associated with visions of mosses, grasses and ferns. 'The silent vegetation sends me images and sounds', the artist emphasises,${ }^{76}$ finding in photography an appropriate language to tackle the domain of the invisible.

In Pascaline Marre's work, ${ }^{77}$ the waves of the Black Sea wash peacefully over the surface of a photograph that at first glance conceals its secret. However, her image, dedicated to a survivor called Lussaper, suddenly reveals an intention: the quest for recognition of the places where the Armenians were swallowed up. The dedication to Lussaper reminds us that the Black Sea's waters belong to the history of the genocide, having closed over the deportees of the coastal regions.

The photographic work of Bardig Kouyoumdjian similarly questions the deadly turn of places against the population. Rather belatedly, this grandson of an escapee was led by his search to the Syrian Desert. He brought back a series of photographs published by Actes Sud in 2005, the year commemorating the ninetieth anniversary of the genocide. ${ }^{78}$ All are born of an encounter with nothingness. 'For five hours by motorbike, off the beaten track, the landscape is the same', he notes under one of the pictures. 'No trace of life, you are surrounded by horizon'. ${ }^{79}$ The infinite empty space gradually disorients the spectator.

Nevertheless, by capturing the desert, by placing it in the rigorous framework of an image, the photographer has also channelled its influence: 'boxed up', the vastness is submitted to reflection. The gaze can now consider what was once the ultimate crime scene, burning and endless. Divided up in this way, space becomes an intelligible site for history.

The desert finally calls us to reflect upon the secrecy in which mass crimes veil themselves in order to succeed. Thus, it becomes an allegory for the perfect crime, as also seen in a poster against Turkish negationism by Ruben Malayan ${ }^{80}$ that shows a desert expanse surrounded by mountains, with a barely visible skeleton lying at the foot of a dead shrub. ${ }^{81}$ Using this montage, the author plays on the registers of absence ('There were no concentration camps in 1915', reads the caption) 
and of the invisible ('There was the Syrian Desert'), to denounce the lie that the State is still getting away with perpetration.

The images of the desert have therefore replaced the brutality with another theme, touching upon the paradoxical modernity of this mass murder. To end up here, they suggest, a political view of space had to be applied to the Ottoman Empire, leaving nothing to chance. In fact, a new generation of historians have demonstrated the mathematical operation of a social and territorial 'engineering' designed to get rid of the undesirables there, with their disappearance allowing the Turks here to create a nation-state. ${ }^{82}$

Bardig Kouyoumdjian's work is of further interest owing to a change of focus that leads it to look 'close to the ground', as said by the advocates of microhistory. This is where we find the second enigma: that of the material traces of the genocide, a matter of obsession for all those studying the region. By exploring the immenseness of North Syria in this way, Kouyoumdjian found bones that had been brought back to the surface by water and agricultural ploughing. The photographer inscribed these fragile remains in two ways. The first was an ersatz tomb; a 'cardboard box, wrapped in a black cloth', was taken back to the Parisian photographer's home as a sign of personal appropriation of a symbolic ascendance. ${ }^{83}$ The second was the photograph that rescued the bones from the void and offered them up to collective memory. ${ }^{84}$ Although still very little in view of the multitude of skeletons buried under the earth for a century, these fragments are nevertheless the parts representing the whole, tangible traces of a world of graves that forms the substructure of contemporary Turkey. ${ }^{85}$ The bones are tightly framed in the shot, yet this treatment has allowed human remains to be saved by a displacement to an aesthetic space, where they are finally freed from their servitude to a physical place that condemned them to dust. The civil war that has been ravaging Syria since March 2011 did not spare the old Armenian bones, which have been repeatedly destroyed by the conflict's bombs. The Deir-es-Zor Memorial, which was dynamited in September 2014 by the jihadist forces of the self-proclaimed Islamic State of the Levant, was a target for those still disturbed by the fragments of truth. The photographic act becomes a retroactive rescue operation, a way of sheltering a few bones in portable spaces of memory.

The enigma of traces led Pascaline Marre not to the bones but to living people in Anatolia today. By walking the streets of the old Armenian quarter, by scrutinising the urban buildings, by stepping inside domestic interiors, her detailed art questions a strange closeness: the day-to-day proximity of the citizens with their neighbours from the past, victims of mass murder who were swallowed up in the darkness of lies. The wings of daily existence are filled with absent lives: rooms invaded by debris, crosses etched in the stone, unclear shapes in the corners of houses. How can anyone therefore believe in the undivided reign of a unified memory in Turkey, when the signs of an abolished otherness are still visible everywhere? Or does the power of the negationist siphon lie precisely in engulfing a world of signs and meaning? It seems everything is there, visible and familiar, but there is no way of getting to the truth of the older layers. It is like looking at a palimpsest. 
Finally, the living themselves sometimes find that their bodies carry traces. This is the last enigma posed by the memory of the genocide that I wish to evoke. It shifts the focus onto the men and women of Turkey who, despite themselves, find that the imperious resurgence of the truth is catching them up. To understand this, we must remember that the destruction of the Armenian community took place via the forced integration of tens of millions of women and children into Muslim households after they were kidnapped, sold and soon dispossessed of their first identity. After Lausanne, the League of Nations stopped demanding that the Turks free the Armenians they were still holding. ${ }^{86}$ It thus considered the matter closed. Yet with the situation becoming a taboo, a memory managed to survive in private within families, resolutely mute for decades, until the passage of time finally allowed the ancestors to whisper their stories to their grandchildren. In $M y$ Grandmother: An Armenian-Turkish Memoir, ${ }^{87}$ Fethiye Çetin gives an account of this revelation; it created astonishment in Turkey, where many of her fellow citizens began looking at their own bodies as the troubling receptacle of hidden violence - the human legacy in flesh and blood of a major event ignored by their national history.

The photographic corpus on the Armenian genocide was long limited to rare images that were taken by non-professionals. Held up as proof after the war, they evaporated after the Armenian Question fell off diplomatic agendas. Later, they provided the heirs of the catastrophe with a pillar of tangible representations on which they could base their demands for international recognition of the genocide. Every fight needs its icons. These photographs were invariably reproduced because of their supposed capacity to record the past and to authenticate it by saying: 'That, there it is, that's it!'88

However, the time came for the images to be renewed. To achieve this, professional photographers and artists visited the sites to tackle the question of afterwards. Walking through the desert or stepping inside homes, the photographers saw space as a problematic stage: a palimpsest-place, where the signs of an abolished otherness remain highly visible - for those who know how to look. Placing the enigma of traces and remains at the heart of the mission, they provide memory with aesthetic frameworks, allowing it to metabolise the void to create collective landmarks.

\section{Notes}

1 Translated from the author's French by Cadenza Academic Translations.

2 P. Pachet, 'Indifférence, Fabulation et Negation', in C. Coquio (ed.), L'histoire Trouée: Négation et Témoignage (Nantes, L'Atalante, 2003), 249-55.

3 T. Hoffmann \& G. Koutcharian, 'Images that Horrify and Indict: Pictorial Documents on the Persecution and Extermination of Armenians from 1877 to 1922', Armenian Review, 45 (1992), 53-184; D. Kévonian, 'Fotografie del Genocidio Degli Armeni e Poste in Gioco della Storiografia', Memoria e Ricerca, Rivista di Storia Contemporanea. Fotografia e Violenza: Visioni della Brutalità dalla Grande Guerra ad Oggi, 20 (2005), 93-110; D. Kévonian, 'Photographie, 
Génocide et Transmission: L'exemple Arménien', Les Cahiers de la Shoah, 8:1 (2005), 119-49; B. Guerzoni, Cancellare un Popolo. Immagini e Documenti del Genocidio Armeno (Milan, Mimesis, 2013).

4 Looking purely at the question of the Armenian genocide, see in particular S. Rollet, Une Éthique du Regard: Le Cinéma Face à la Catastrophe, d'Alain Resnais à Rithy Panh (Paris, Hermann, 2011); M.-A. Baronian, Mémoire et Image: Regards sur la Catastrophe Arménienne (Lausanne, L’Âge d'Homme, 2013).

5 According to the distinction that guides André Rouillé's reflection in $\mathrm{La}$ Photographie: Entre Document et Art Contemporain (Paris, Gallimard, 2005).

6 G. Tchalkhouchian, Le Livre Rouge (Paris, Veradzenount, 1919), p. 38.

7 This is the name of the Turkish revolutionary and nationalist political organisation that governed the Ottoman Empire from 1908 (also known as the Young Turk Party). The most extremist wing of the organisation occupied key posts in government during the First World War and planned the Armenian genocide.

8 Tchalkhouchian, Le Livre Rouge, pp. 105-7.

9 Two decrees (from 28 August and 10 September 1915 respectively) forbade photographs of the deportees. See Kévonian, 'Fotografie del Genocidio', 94.

10 As Susan Sontag emphasises, it was not until the availability of lightweight equipment and the replacement of plates by film that cameras were able to enter the battlefield. The Spanish Civil War was the first conflict caught live in photographs. See S. Sontag, Devant la Douleur des Autres (Paris, Christian Bourgois, 2003), p. 28.

11 With reference to G. Didi-Huberman, Images malgré tout (Paris, Éditions de Minuit, 2003). The production context for photographs of the genocide is analysed in Guerzoni, Cancellare un Popolo, pp. 133-207.

12 On this solemn note of protest from France, Great Britain and Russia, see

S. Garibian, Le Crime contre l'Humanité au Regard des Principes Fondateurs de l'État Moderne: Naissance et Consécration d'un Concept (Brussels, Bruylant, 2009), p. 82 onwards.

13 Importantly, the great eyewitness of the genocide, Armin Wegner, speaks of 'images of terror and accusation' with reference to the photographic plates that he hid in his belt. See Anna Maria Samuelli et al., (eds), Armin T. Wegner e gli Armeni in Anatolia, 1915: Immagini e Testimonianze (Milan, Guerini e Associati, 2005), p. 71 .

14 According to the estimates of the authors, thirty-two out of two hundred images directly concern the genocide. See Hoffmann \& Koutcharian, 'Images that Horrify and Indict', 55.

15 The Armenian National Institute (Washington, DC) has put part of the Wegner Collection online. URL: http://www.armenian-genocide.org (accessed 15 March); for an in-depth presentation of the different photographic collections, refer to the works listed in note 2, as well as the website of the Armenian Genocide Museum. URL: http://www.genocide-museum.am (accessed 15 March).

16 It is important to remember that during the first global conflict there was a military alliance between the Reich and the Ottoman Empire.

17 Wegner published several works on the subject, in particular see A. Wegner, 
Der Weg ohne Heimkehr (Dresden, Sibyllen Verlag, 1919); and Im Hause der Glückseligkeit: Aufzeichnungen aus der Türkei (Dresden, Sibyllen Verlag, 1920).

18 Samuelli et al., Armin T. Wegner e gli Armeni in Anatolia, p. 37.

19 For a photo album showing mass graves, published in 1917 in Tiflis, where there was a large and influential Armenian community see Kévonian, 'Fotografie del Genocidio', 97; the reproduction of a photograph taken on the Russian front can be found in Hoffmann and Koutcharian, 'Images that Horrify and Indict', 90.

20 H. Barby, Au Pays de l'Épouvante: L'Arménie Martyre (Paris, Albin Michel, 1917).

21 The place is now called Tbilisi, the current capital of the Republic of Georgia.

22 Barby, Au Pays de l'Épouvante, p. 89.

23 A subject of the Russian Empire, this Georgian published an article on Baskane in the periodical Armenia $i$ Voïna, 10 (1916); it is used by Tchalkhouchian in Le Livre Rouge, pp. 47-50.

24 These are Kipiani's words, cited by Tchalkhouchian in Le Livre Rouge, p. 49.

25 Ibid.

26 See H. Dumas \& R. Korman, 'Espaces de la Mémoire du Génocide des Tutsis au Rwanda: Mémoriaux et Lieux de Mémoire’, Afrique Contemporaine, 238:2 (2011), 22-3.

27 H. Dumas, 'Histoire, Justice et Réconciliation: Les Juridictions Gacaca au Rwanda', Mouvements 53:1 (2008), 110-17; Dumas, 'Gacaca Courts in Rwanda: A Local Justice for a Local Genocide History?’, in C. Delage \& P. Goodrich (eds), The Scene of the Mass Crime: History, Film and International Tribunals (London, Routledge, 2012), 57-74.

28 International Criminal Tribunal for Rwanda, established in 1994 in Arusha, Tanzania.

29 During late 1918, in the conquered Ottoman Empire, these were the Administrative Investigation Commission or 'Mazhar' and the courts marshal. See V. Dadrian, The History of the Armenian Genocide: Ethnic Conflict from the Balkans to Anatolia to the Caucasus (New York, Berghahn Books, 2003), pp. 317-43; V. Dadrian \& T. Akçam, Judgment at Istanbul: The Armenian Genocide Trials (New York, Berghahn Books, 2011). There was also the Peace Conference in Paris from January 1919 to August 1920; finally, it is necessary to mention the key role played in the collection of documents by the Information Bureau, created in 1919, on the initiative of the Armenian Patriarchate of Constantinople. See R. Kévorkian, The Armenian Genocide: A Complete History (New York, I. B. Tauris, 2011), p. 4.

30 The first testimonies of this type were published from 1916 in the Blue Book by the British Government entitled The Treatment of Armenians in the Ottoman Empire, 1915-1916. There were documents presented in 1916 by Viscount James Bryce and Arnold J. Toynbee. Also in 1916, the Bericht über die Lage des Armenischen Volkes in der Türkei (Report on the Situation of the Armenian People in Turkey) was published by the pastor Johannes Lepsius in Germany. This document will be examined later.

31 See for example the memoirs of Naïm Bey (chief secretary for the administration 


\section{Anouche Kunth}

of deportees in Alep), transcribed and published by Aram Andonian in The Memoirs of Naïm Bey (London, Hodder \& Stoughton, 1920).

32 The North Mesopotamian sectors of Syria, having contained concentration camps, were searched by the Armenians. See Kévonian, 'Photographie, Génocide et Transmission', 127.

33 The doctor Tevfik Rüştü, a member of the Supreme Health Council, was charged with locating the main graves and pouring quicklime into them to speed up the decomposition of the bodies. See T. Akçam, A Shameful Act: The Armenian Genocide and the Question of Turkish Responsibility (New York, Metropolitan Books, 2006), p. 363.

34 Faced with limbs that had been scattered and ripped apart, Kipiani commented that: 'During the winter, dogs and wolves devoured many of the corpses. This is proven by the scattered hands and feet all across Tchapane.' Kipiani is cited by Tchalkhouchian in Le Livre Rouge, p. 50.

35 See Armenian National Delegation, Mémorandum sur la Question Arménienne (Paris, Imprimerie M. Flinikowski, 1918); Armenian Delegation integral to the Peace Conference, La Question Arménienne devant la Conférence de la Paix (Paris, Imprimerie de P. Dupont, 1919).

36 She herself escaped the roundup of 24 April 1915.

37 She collected the testimonies of this roundup. See the afterword by Marc Nichanian in H. Toroyan \& Z. Essayan, L'Agonie d'un Peuple (Paris, Classiques Garnier, 2013), p. 156.

38 M. Nichanian, Entre l'Art et le Témoignage: La Révolution Nationale, vol. 1 (Geneva, MētisPresses, 2006), p. 258.

39 Andonian, The Memoirs of Naïm Bey. They show photographs of orphans and captives gathered prior to execution. A journalist arrested in Istanbul during the roundup of 24 April 1915 (specifically targeting the Armenian elites of the Ottoman capital), Andonian survived deportation, then, as a refugee in Paris, spent the rest of his life collecting documentation on the genocide, kept in the Nubar Pacha Library.

40 Kévonian, 'Fotografie del Genocidio', 103-4.

41 Dadrian, The History of the Armenian Genocide, pp. 304-5; S. Garibian, 'From the 1915 Allied Joint Declaration to the 1920 Treaty of Sèvres: Back to an International Criminal Law in Progress', Armenian Review, 52:1-2 (2010), 87-102.

42 On this, see D. Kévonian, Réfugiés et Diplomatie Humanitaire: Les Acteurs Européens et la Scène Proche-orientale pendant l'Entre-deux-guerres (Paris, Publications de la Sorbonne, 2004).

43 Garibian, Le Crime contre l'Humanité, p. 98.

44 See for example the many publications of the Swiss pastor Antony Krafft-Bonnard or Frédéric Macler's La Nation Arménienne: Son passé, ses Malheurs (Paris, Librairie Fischbacher, 1924); finally, even Aram Turabian's opus follows the same model as preceding publications, only showing the crime through groups of orphans left in the care of the American charity Near East Relief. See A. Turabian, L'Éternelle victime de la Diplomatie Européenne (Marseille, Imprimerie Nouvelle, 1929). 
45 For an analysis of the American publications, see Kévonian, 'Fotografie del Genocidio', 99-102.

46 A. Slide (ed.), Ravished Armenia and the Story of Aurora Mardiganian (London, Scarecrow Press, 1997), p. 5 onwards.

47 Sévane Garibian studied this film in 'Ravished Armenia (1919): Bearing Witness in the Age of Mechanical Reproduction: Some Thoughts on a Film-Ordeal', in J. Chabot, R. Godin, S. Kappler \& S. Kasparian (eds), Mass Media and the Genocide of the Armenians: One Hundred Years of Uncertain Representation, (Basingstoke, Palgrave, 2015), pp. 37-54.

48 K. Balakian, Hay Goggot'an [Armenian Golgotha] (Vienna, Cong. Mekhitariste, 1922); Guerzoni, Cancellare un Popolo, p. 215.

49 In summer 1916, Pastor Lepsius, President of the Deutsche Orientalische Mission and the Deutsche Armenische Gesellschaft, published twenty thousand copies of Bericht über die Lage des Armenischen Volkes in der Türkei (Report on the Situation of the Armenian People in Turkey).

50 Guerzoni, Cancellare un Popolo, p. 232 onwards.

51 An Armenian student and orphan of the genocide, Tehlirian killed Talaat Pacha, the former Ottoman minister of the interior and the main planner for the extermination program, on the street in Berlin. He was not acting alone, but as part of an operation called Nemesis (the name of the Greek goddess of revenge or righteous anger), piloted by the Armenian Revolutionary Federation.

52 The author wishes to thank Sévane Garibian for this point. See S. Garibian, 'Ordonné par le Cadavre de ma Mère: Talaat Pacha, ou l'Assassinat Vengeur d'un Condamné à Mort', in S. Garibian (ed.), La Mort du Bourreau: Justices et Vengeances Face aux Crimes de Masse (Paris, Pétra, forthcoming); the shorthand minutes of Soghomon Tehlirian's trial were published in full in 1921 by German publishers and appeared in French in Justicier du Génocide Arménien (Paris, Éditions Diaspora, 1981), p. 212, in relation to Wegner; see also Frédéric Macler's article on the subject at the time, 'Le Procès de Talaat Pacha', Revue des Études Arméniennes, 3:1 (1922), 139-45, which hardly addresses the photographic proof that Wegner supposedly presented to the tribunal, contrary to the affirmations of Kévonian, 'Fotografie del Genocidio', 103n34.

53 E. Friedrich, Krieg dem Kriege! (Berlin, Verlag, 1924; Munich, Deutsche VerlagsAnstalt, 2004).

54 German, French, English and Dutch.

55 As stated in Sontag, Devant la Douleur des Autres, p. 22.

56 Friedrich, Krieg dem Kriege!, pp. 152-4.

57 Ibid., p. 152. (Translator's note: Quotation back-translated from the Frenchlanguage version of this article.)

58 The novel in question was Franz Werfel's The Forty Days of Musa Dagh, first published in Vienna in 1933.

59 On these words from Hitler, see Y. Ternon, 'La Qualité de la Prevue: À Propos des Documents Andonian et de la Petite Phrase d'Hitler', in CDCA (ed.), Actualité du Génocide des Arméniens (Paris, Édipol, 1999), pp. 135-42.

60 On the effervescence of this commemoration in Soviet Armenia, see 
C. Mouradian, L'Arménie: De Staline à Gorbatchev: Histoire d'une République Soviétique (Paris, Ramsay, 1990), p. 284.

61 Garibian, Le Crime contre l'Humanité, pp. 101-2.

62 Samuelli et al., Armin T. Wegner e gli Armeni in Anatolia, p. 219.

63 J.-M. Carzou, Un Génocide Exemplaire, Arménie 1915 (Paris, Flammarion, 1975).

64 It was not until 1992 that two researchers conducted a critical examination of the available corpus. The work was indispensable in elevating images to the rank of historical sources. The article in question was that cited above, Hoffmann \& Koutcharian, 'Images that Horrify and Indict'.

65 See the analyses in Kévonian, 'Photographie, Génocide et Transmission', 122-3, 141-2, on this event (Images $d u$ XX $X^{\mathrm{e}}$ Siècle: Le Génocide des Arméniens) held by the organisation Terre et Culture.

66 This trait is remarkably different to the possibility of using a telephoto lens to film scenes of the massacre of the Tutsis in Rwanda. For example, a short video extract was shown at the Rwanda - 2014 exhibition at the Mémorial de la Shoah (Paris's Holocaust memorial), upon the twenty-year commemoration of the genocide.

67 On representations of victims in the Christian interpretive framework, see J. Hanrot, La Madone de Bentalha: Histoire d'une Photographie (Paris, Armand Colin, 2012), p. 69 onwards.

68 On this subject, see Baronian, Mémoire et Image.

69 Rollet's analysis of Atom Egoyan's filmed images provides useful reading on this. See Rollet, Une Éthique du Regard, p. 120 onwards.

70 This historiographical current was born in Italy at the end of the 1970s and proposes to reduce the scale of analysis to draw attention not to structures but to individuals seen 'through the magnifying glass'.

71 Kévorkian, The Armenian Genocide, p. 625 onwards.

72 O. Razac, Barbed Wire: A Political History (London, Profiles Books, 2002).

73 Carzou, Un Génocide Exemplaire, p. 210.

74 A. Poidebard, Carnet de Route d'un Aumônier de Cavalerie: D'Arménie au Front Français, Mai 1914-décembre 1917 (Paris, Payot et Cie, 1919), p. 1.

75 Here I refer readers to an article on the relationships between mass murder and the landscape. See A. Kunth, 'De la Catastrophe au Chaos: Mémoires Paysagères de l'Arménie', Théorème 19 (2014), 56-67.

76 Artist's words on his work, 'Traces 1', displayed at the Maison de la Culture Yiddish, Paris, winter 2014-15.

77 P. Marre, Fantômes d'Anatolie: Regards sur le Génocide Arménien (Pascaline Marre, 2014). See the photographer's personal site. URL: http://www. pascalinemarre.com (accessed 14 April 2015).

78 B. Kouyoumdjian \& C. Siméone, Deir-es-Zor. Sur les Traces du Génocide Arménien de 1915 (Arles, Actes Sud, 2005).

79 Kouyoumdjian \& Siméone, Deir-es-Zor, p. 94.

80 Ruben Malayan is a founding member of 'Armenian Genocide in Contemporary Graphic \& Art Posters'. URL: http://www.armeniangenocideposters.org (accessed 14 April 2015). 
81 Poster entitled 'Syrian Desert', created for the ninety-first annual commemorations of 24 April 2006.

82 See the works of Fuat Dundar, Crime of Numbers: The Role of Statistics in the Armenian Question (1878-1918) (New Brunswick, Transaction Publishers, 2010); U. Ü. Üngör, 'Seeing Like a Nation-State: Young Turk Social Engineering in Eastern Turkey, 1913-1950', in D. Schaller \& J. Zimmerer (eds), Late Ottoman Genocides: the Dissolution of the Ottoman Empire and Young Turkish Population and Extermination Policies (London, Routledge, 2009), pp. 9-33.

83 Kouyoumdjian \& Siméone, Deir-es-Zor, p. 113.

84 Ibid., pp. 111-12, 117.

85 As emphasised in Kévorkian, The Armenian Genocide, p. 1. The physical destruction of the Armenians was seen as the necessary condition for the construction of a Turkish nation state.

86 J.-M. Chaumont, Le Mythe de la Traite des Blanches: Enquête sur la Fabrication d'un Fléau (Paris, La Découverte, 2009), pp. 205-18.

87 F. Çetin, My Grandmother: An Armenian-Turkish Memoir (London, Verso, 2012).

88 R. Barthes, La Chambre Claire: Note sur la Photographie (Paris, L'Étoile, Gallimard, Le Seuil, 1980), pp. 15-16. 